\title{
Comparative proteomic analysis of human serum before and after liver transplantation using quantitative proteomics
}

\author{
Ruohan Zhang ${ }^{1}$, Minglin Ou ${ }^{1}$, Yue Zhang ${ }^{1}$, Qiang Yan ${ }^{1}$, Huaizhou Chen ${ }^{1}$, Liusheng \\ $\mathrm{Lai}^{1}$, Ying $\mathrm{Li}^{1}$, Feilong $\mathrm{Xu}^{1}$, Donge Tang ${ }^{2}$, Xuyong Sun ${ }^{3}$, Jianhui Dong ${ }^{3}$, Yong Dai ${ }^{2}$ \\ and Weiguo Sui ${ }^{1}$ \\ ${ }^{1}$ Guangxi Key Laboratory of Metabolic Diseases Research, Nephrology Department of Guilin 924st Hospital, Guilin, Guangxi \\ 541002, P.R. China \\ ${ }^{2}$ Clinical Medical Research Center, The Second Clinical Medical College of Jinan University, Shenzhen People's Hospital, \\ Shenzhen, Guangdong 518020, P.R. China \\ ${ }^{3}$ Guangxi Key Laboratory for Transplantation Medicine Guangxi, Institute of Transplant Medicine, Department of Organ \\ Transplantation in Guangzhou Military Region, 923st Hospital, Nannning 530021, P.R. China \\ Correspondence to: Yong Dai, email: daiyong22@aliyun.com \\ Weiguo Sui, email: suiwg@163.com \\ Keywords: liver transplantation; proteomics; iTRAQ; protein markers; pathway \\ Received: June 19, $2018 \quad$ Accepted: February 01, $2019 \quad$ Published: April 02, 2019 \\ Copyright: Zhang et al. This is an open-access article distributed under the terms of the Creative Commons Attribution License 3.0 \\ (CC BY 3.0), which permits unrestricted use, distribution, and reproduction in any medium, provided the original author and source \\ are credited.
}

\section{ABSTRACT}

Liver cancer is the second leading cause of cancer mortality worldwide. Safer and more effective diagnostic methods for liver cancer are desirable, and biomarkers represent a potentially alternative method for diagnosis. The present study was designed to identify liver cancer biomarkers. We quantified the changes in serum protein levels between liver transplantation and healthy (control) females using isobaric tags for relative and absolute quantitation (iTRAQ) as well as proteomic analysis. A total of 1399 proteins were identified; of these, three proteins showed significantly different concentrations between the before transplantation group and the control group. These proteins may thus be relevant to liver cancer and constitute potential liver cancer biomarkers.

\section{INTRODUCTION}

Liver cancer is the second leading cause of cancer mortality worldwide, causing more than 700,000 deaths annually [1]. Liver transplantation (LT) is the best curative treatment modality, achieving up to $91 \% 1$-year survival post-transplantation [2]. However, finding the right donor liver is rare, and the patient must live as long as possible to wait for the liver from an appropriate donor. Therefore, the sooner the disease is diagnosed, the better. A safer and more effective diagnostic method is desirable. Biomarkers represent a potentially alternative method for diagnosis.

Proteomic technologies have enabled the identification of novel protein biomarkers [3]. Isobaric tags for relative and absolute quantification (iTRAQ) is a technique developed by the Applied Biosystems Incorporation [4]. In the present study, iTRAQ was used to analyse the total protein content of serum from patients with LT. iTRAQ was combined with Gene Ontology (GO) and pathway analysis to identify proteins that are differentially expressed in LT and determine their predicted functions.

\section{RESULTS}

\section{Protein identification}

In this iTRAQ quantification project, there were 5 homogeneous samples named A, B, C, D, E, and we performed 1 technical duplicate experiment. In total, 401198 spectrums were generated, and 6173 peptides and 1399 proteins were identified with the following cutoff: Mascot Percolator [5] Q-value $\leq 0.01$ (more details on the method page of the MS/MS Ion Search). 


\section{Protein quantification}

These proteins, from the B-VS-A, were divided into 112 upregulated by ratio_B_114/A_113>1.2 (Table 1). Twenty-two proteins were identified, which were divided by a ratio $>2$.

\section{COG annotation for all identified proteins}

All of the identified proteins were classified into different COG functional categories and subsequently into 23 subcategories (Figure 1). Most of these proteins were involved in "post-translational modification, protein turnover, chaperones" and in "general function prediction only".

\section{Pathway enrichment analysis of DEPs}

Data from Figure 1 can be compared with the data in Figure 2, which shows that the P-value of retinol metabolism is the lowest in the B-VS-A pathway. The rich factor is the ratio of differentially expressed protein number annotated in this pathway to all proteins annotated in this pathway. A greater rich factor value corresponds to a greater intensiveness. The $\mathrm{P}$-value ranges from $0 \sim 1$, and a lower P-value indicates greater intensiveness (Figure 2). The KEGG pathway of retinol metabolism is shown in Figure 3. Perisinusoidal stellate cells of the liver play important roles in retinol metabolism and fibrosis [6].

There are 6 differentially expressed proteins annotated in retinol metabolism (Table 2), which are alcohol dehydrogenase $1 \mathrm{~A}$; epididymis luminal protein 9; alcohol dehydrogenase IB (Class I), beta polypeptide, isoform CRA_a; alcohol dehydrogenase 6; aldehyde oxidase and alcohol dehydrogenase 4.

\section{DISCUSSION}

Quantification of the proteins via iTRAQ analysis has been suggested to be a suitable strategy for the identification of biomarkers since iTRAQ allows the comparison of protein abundance among samples by measuring the peak intensities of reporter ions released from the iTRAQ-tagged peptides. In this study, iTRAQ was combined with Gene Ontology (GO) and pathway analysis to identify the proteins that are differentially expressed in LT and determine their predicted functions.

Among the differentially expressed proteins in Table 1 and based on published studies, protein S100-P was found to be relevant to liver cancer. However, in the other groups, C-VS-A_up, D-VS-A_up and E-VS-A_up, S100-P was not significantly upregulated.

S100 calcium-binding protein $\mathrm{P}(\mathrm{S} 100 \mathrm{P})$ is a protein that is encoded by the S100P gene in humans [7]. The protein encoded by this gene is a member of the S100 family of proteins containing 2 EF-hand calcium-binding motifs. S100 proteins are localized in the cytoplasm and/ or nucleus of a wide range of cells and are involved in the regulation of a number of cellular processes, such as cell cycle progression and differentiation. S100 genes include at least 13 members that are located as a cluster on chromosome 1q21; however, this gene is located at $4 \mathrm{p} 16$. This protein, in addition to binding $\mathrm{Ca} 2+$, also binds $\mathrm{Zn} 2+$ and $\mathrm{Mg} 2+$. This protein may play a role in the aetiology of prostate cancer [8]. S100P regulates the calcium signal transduction pathway to mediate cytoskeletal interactions and is induced by the prostaglandin E2 (PGE2)/EP4) receptor signalling pathway in colon cancer cells [9]. The ectopic expression of S100P in SW 480 CRC promotes invasion and metastasis and decreases sensitivity to 5-FU in vitro [10]. The results of Hui Dong et al. indicated that S100P was upregulated in HCC, suggesting a possible role for $\mathrm{S} 100 \mathrm{P}$ in liver cancer. The increased expression of both CCL20 and S100P genes was detected in HCC by quantitative RT-PCR, although they were found to be significantly upregulated in HepG2 but not in HCC SAGE data [11].

In this study, we found that the concentration of $\mathrm{S} 100 \mathrm{P}$ in the serum before transplantation (class B) was $5.38 \mathrm{x}$ higher than that of the control group (class A). The GO biological processes associated with S100P were cellular process, localization, locomotion, response to stimulus and single-organism process. The GO cellular components associated with S100P were cell part and organelle. The GO molecular function associated with S100P was binding.

Aldehyde oxidase (AO) is a metabolizing enzyme and plays a very important role in the metabolization of numerous drugs. AO catalyses the oxidation of aldehydes into carboxylic acid and catalyses the hydrolysation of some heterocycles. In addition, AO can catalyse the oxidation of both cytochrome P450 (CYP450) and monoamine oxidase (MAO) intermediate products [12]. However, in the other groups, C-VS-A_up, D-VS-A_up and E-VS-A_up, S100-P was not significantly upregulated.

We found that the concentration of $\mathrm{AO}$ in the serum of patients before transplantation (class B) was $1.47 \mathrm{x}$ lower than that of the control group (class A). The GO biological process associated with AO were cellular process, metabolic process, and response to stimulus. The GO cellular component associated with $\mathrm{AO}$ was cell parts. The GO molecular function associated with $\mathrm{AO}$ were binding, catalytic activity, and electron carrier activity.

In conclusion, iTRAQ technology, which represents a relatively new strategy for proteomic analysis, was used here to study the changes in protein expression associated with liver cancer. This approach identified 2 significantly differentially expressed proteins ( $\mathrm{S} 100 \mathrm{P}$ and aldehyde oxidase) that were previously reported to be related to liver cancer. The MFs, CCs and BPs associated with these proteins indicate that they may be suitable liver biomarkers, which may improve the timeliness and accuracy of 
Table 1: The upregulated proteins in serum samples of liver transplantation (Part of the data)

\begin{tabular}{|c|c|c|c|}
\hline No. & Protein_ID & Description & Ratio_B_114/A_113 \\
\hline 1 & $\operatorname{tr}|J 3 Q R K 0| J 3 Q R K 0 \_H U M A N$ & $\begin{array}{l}\text { Integrin beta-4 (Fragment) } \mathrm{OS}=\mathrm{Homo} \text { sapiens } \mathrm{GN}=\mathrm{ITGB} 4 \\
\qquad \mathrm{PE}=1 \mathrm{SV}=1\end{array}$ & 10 \\
\hline 2 & 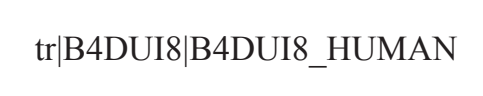 & $\begin{array}{l}\text { cDNA FLJ52761, highly similar to Actin, aortic smooth } \\
\text { muscle OS=Homo sapiens } \mathrm{PE}=2 \mathrm{SV}=1\end{array}$ & 10 \\
\hline 3 & sp|Q3SY84|K2C71_HUMAN & $\begin{array}{l}\text { Keratin, type II cytoskeletal } 71 \mathrm{OS}=\text { Homo sapiens } \\
\qquad \mathrm{GN}=\mathrm{KRT} 71 \mathrm{PE}=1 \mathrm{SV}=3\end{array}$ & 10 \\
\hline 4 & sp|Q8IYL3|CA174_HUMAN & $\begin{array}{l}\text { UPF0688 protein } \mathrm{C} \text { 1orf174 OS=Homo sapiens } \\
\mathrm{GN}=\mathrm{C} 1 \text { orf174 } \mathrm{PE}=1 \mathrm{SV}=2\end{array}$ & 10 \\
\hline 5 & $\operatorname{tr}|J 3 K S Q 2| J 3 K S Q 2 \_H U M A N$ & $\begin{array}{l}\text { Clathrin heavy chain } 1 \text { (Fragment) } \mathrm{OS}=\text { Homo sapiens } \\
\qquad \mathrm{GN}=\mathrm{CLTC} \mathrm{PE}=1 \mathrm{SV}=1\end{array}$ & 9.594 \\
\hline 6 & $\operatorname{tr}|\mathrm{A} 8 \mathrm{~K} 6 \mathrm{~A} 5| \mathrm{A} 8 \mathrm{~K} 6 \mathrm{~A} 5$ HUMAN & $\begin{array}{c}\text { cDNA FLJ77742, highly similar to Homo sapiens integrin, } \\
\text { alpha } 5 \text { (fibronectin receptor, alpha polypeptide), } \\
\text { mRNA OS=Homo sapiens } \mathrm{PE}=2 \mathrm{SV}=1\end{array}$ & 9.575 \\
\hline 7 & tr|Q86UW0|Q86UW0_HUMAN & $\begin{array}{l}\text { Ovarian epithelial carcinoma-related protein } \mathrm{OS}=\text { Homo } \\
\qquad \text { sapiens } \mathrm{PE}=2 \mathrm{SV}=1\end{array}$ & 8.757 \\
\hline 8 & $\begin{array}{c}\operatorname{tr}|\mathrm{A} 0 \mathrm{~A} 024 \mathrm{R} 2 \mathrm{~T} 8| \mathrm{A} 0 \mathrm{~A} 024 \mathrm{R} 2 \mathrm{~T} 8 \\
\text { HUMAN }\end{array}$ & $\begin{array}{c}\text { Endonuclease G-like 1, isoform CRA_b OS=Homo } \\
\text { sapiens GN=ENDOGL1 } \mathrm{PE}=4 \mathrm{SV}=1\end{array}$ & 7.551 \\
\hline 9 & tr|D6RGG3|D6RGG3_HUMAN & $\begin{array}{l}\text { Collagen alpha- } 1(\mathrm{XII}) \text { chain } \mathrm{OS}=\text { Homo sapiens } \\
\qquad \mathrm{GN}=\mathrm{COL} 12 \mathrm{~A} 1 \mathrm{PE}=1 \mathrm{SV}=1\end{array}$ & 6.66 \\
\hline 10 & $\mathrm{sp}|\mathrm{P} 25815| \mathrm{S} 100 \mathrm{P} \_$HUMAN & $\begin{array}{l}\text { Protein } \mathrm{S} 100-\mathrm{P} \text { OS }=\text { Homo sapiens } \mathrm{GN}=\mathrm{S} 100 \mathrm{P} \mathrm{PE}=1 \\
\qquad \mathrm{SV}=2\end{array}$ & 5.38 \\
\hline 11 & sp|Q7L523|RRAGA_HUMAN & $\begin{array}{l}\text { Ras-related GTP-binding protein } \mathrm{A} \mathrm{OS}=\text { Homo sapiens } \\
\qquad \mathrm{GN}=\mathrm{R} \mathrm{RAGA} \mathrm{PE}=1 \mathrm{SV}=1\end{array}$ & 4.567 \\
\hline 12 & tr|Q7Z3Y6|Q7Z3Y6_HUMAN & $\begin{array}{l}\text { Rearranged VH4-34 V gene segment (Fragment) } \\
\text { OS=Homo sapiens GN=VH4-34 PE=4 SV=1 }\end{array}$ & 4.433 \\
\hline 13 & $\begin{array}{c}\operatorname{tr}|\mathrm{A} 0 \mathrm{~A} 0 \mathrm{C} 4 \mathrm{DH} 43| \mathrm{A} 0 \mathrm{~A} 0 \mathrm{C} 4 \mathrm{DH} 43 \\
\text { HUMAN }\end{array}$ & $\begin{array}{l}\text { Uncharacterized protein (Fragment) } \mathrm{OS}=\text { Homo sapiens } \\
\qquad \mathrm{PE}=4 \mathrm{SV}=1\end{array}$ & 2.93 \\
\hline 14 & 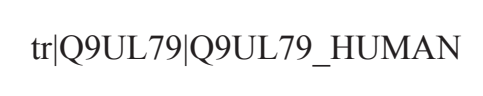 & $\begin{array}{l}\text { Myosin-reactive immunoglobulin light chain variable } \\
\text { region (Fragment) } \mathrm{OS}=\text { Homo sapiens } \mathrm{PE}=2 \mathrm{SV}=1\end{array}$ & 2.865 \\
\hline 15 & sp|Q9UM07|PADI4_HUMAN & $\begin{array}{l}\text { Protein-arginine deiminase type- } 4 \mathrm{OS}=\text { Homo sapiens } \\
\qquad \mathrm{GN}=\mathrm{PADI} 4 \mathrm{PE}=1 \mathrm{SV}=2\end{array}$ & 2.683 \\
\hline 16 & $\operatorname{tr|B4E380|B4E380\_ HUMAN~}$ & Histone $\mathrm{H} 3 \mathrm{OS}=$ Homo sapiens $\mathrm{PE}=2 \mathrm{SV}=1$ & 2.605 \\
\hline 17 & 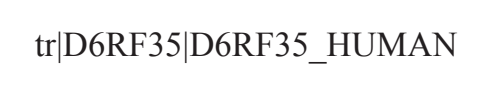 & $\begin{array}{l}\text { Vitamin D-binding protein } \mathrm{OS}=\text { Homo sapiens } \mathrm{GN}=\mathrm{GC} \\
\qquad \mathrm{PE}=1 \mathrm{SV}=1\end{array}$ & 2.355 \\
\hline 18 & 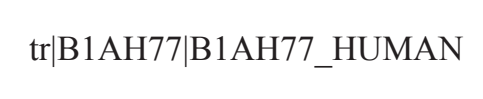 & $\begin{array}{l}\text { Ras-related } \mathrm{C} 3 \text { botulinum toxin substrate } 2 \mathrm{OS}=\text { Homo } \\
\text { sapiens } \mathrm{GN}=\mathrm{RAC} 2 \mathrm{PE}=1 \mathrm{SV}=1\end{array}$ & 2.195 \\
\hline 19 & sp|P62805|H4_HUMAN & $\begin{array}{l}\text { Histone } \mathrm{H} 4 \mathrm{OS}=\text { Homo sapiens } \mathrm{GN}=\mathrm{HIST} 1 \mathrm{H} 4 \mathrm{~L} \mathrm{PE}=2 \\
\mathrm{SV}=1\end{array}$ & 2.172 \\
\hline 20 & 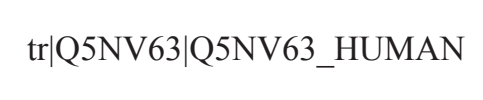 & $\begin{array}{l}\text { V1-4 protein (Fragment) } \mathrm{OS}=\text { Homo sapiens } \mathrm{GN}=\mathrm{V} 1-4 \\
\qquad \mathrm{PE}=4 \mathrm{SV}=1\end{array}$ & 2.092 \\
\hline 21 & sp|P68871|HBB_HUMAN & $\begin{array}{l}\text { Hemoglobin, beta } \mathrm{OS}=\text { Homo sapiens } \mathrm{GN}=\mathrm{HBB} \mathrm{PE}=3 \\
\qquad \mathrm{SV}=1\end{array}$ & 2.081 \\
\hline 22 & 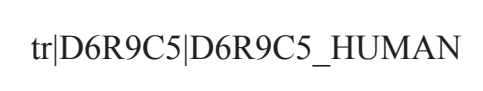 & $\begin{array}{l}\text { Osteopontin (Fragment) } \mathrm{OS}=\text { Homo sapiens } \mathrm{GN}=\mathrm{SPP} 1 \\
\qquad \mathrm{PE}=1 \mathrm{SV}=1\end{array}$ & 2.078 \\
\hline
\end{tabular}




\title{
COG Function Classification of homo Sequence
}

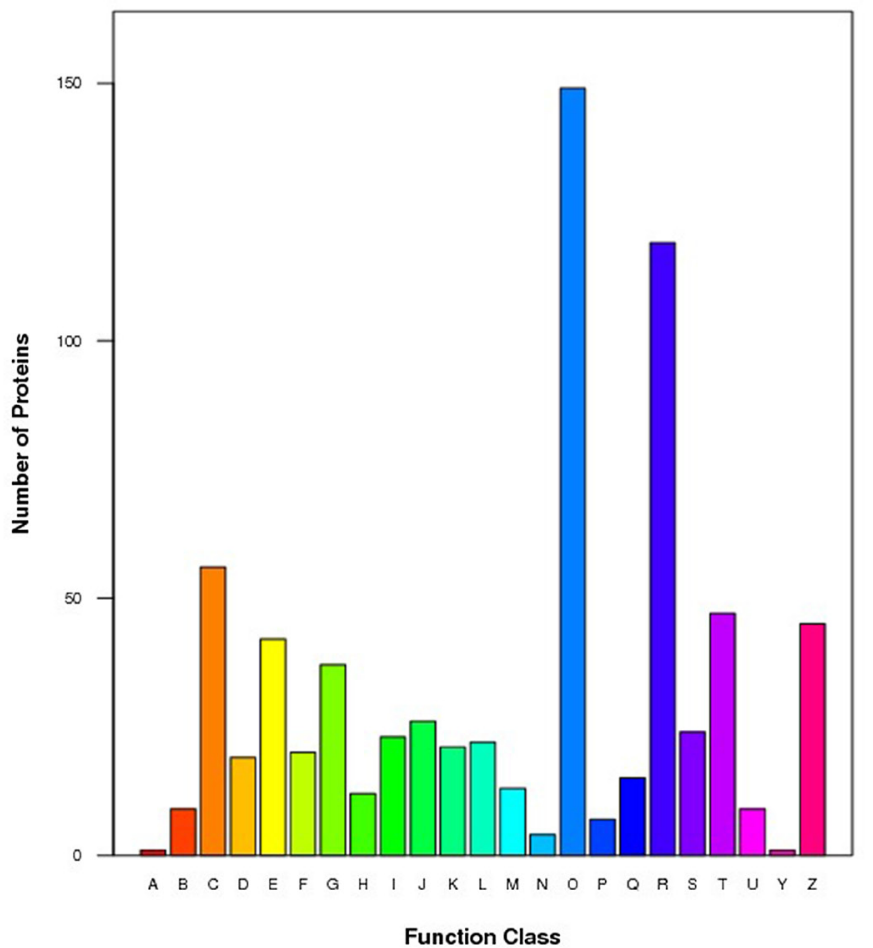

\author{
A: RNA processing and modification \\ B: Chromatin structure and dynamics \\ C: Energy production and corversion \\ D: Cell cycle control, cøll division, chromosome partitioning \\ E: Amino acid transport and metabolism \\ F: Nucleotide transport and metabolism \\ G: Carbohydrate transport and metabolism \\ H: Coenzyme transport and metabolism \\ I: Lipid transport and metabolism \\ $\mathrm{J}$ : Translation, ribosomal structure and biogenesis \\ K: Transcription \\ L: Replication, recombination and repair \\ M: Cell wall/membrane/envelope biogenesis \\ $\mathrm{N}$ : Cell motility \\ O: Posttranslational modification, protein turnover, chaperones \\ P: Inorganic ion transport and metabolism \\ Q: Secondary metabolites biosynthesis, transport and catabolism \\ R: General function prediction only \\ S: Function unknown \\ $\mathrm{T}$ : Signal transduction mechanisms \\ $\mathrm{U}$ : Intracellular trafficking, secretion, and vesicular transport \\ Y: Nuclear structure
}

Z: Cytoskeleton

Figure 1: Histogram of the GOG Analysis. x-axis displays the COG term, y-axis displays the corresponding protein count illustrating the protein number of different function.
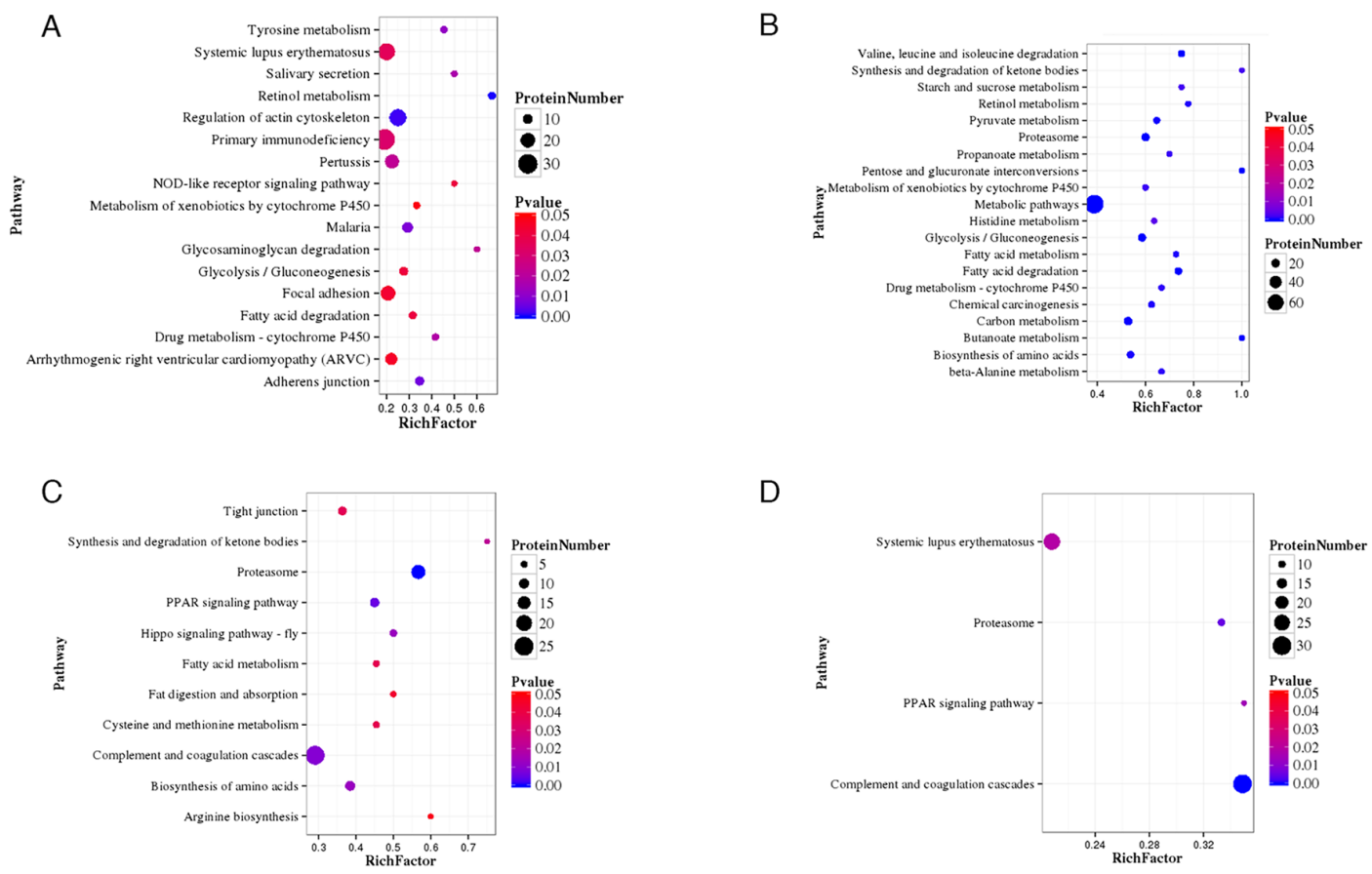

Figure 2: (A):class B vs class A; (B):class C vs class A; (C):class D vs class A; (D):class E vs class A Statistics of pathway enrichment of differentially expressed proteins in each pairwise. RichFactor is the ratio of differentially expressed protein number annotated in this pathway term to all protein number annotated in this pathway term. Greater richFator means greater intensiveness. Pvalue ranges from $0 \sim 1$, and less Pvalue means greater intensiveness. 
Table 2: differentially expressed protein annotated in retinol metabolism

\begin{tabular}{|c|c|c|c|}
\hline No. & Protein_ID & Description & Ratio_B_114/A_113 \\
\hline 1 & $\begin{array}{l}\text { sp } \mid \text { P00325|ADH1B } \\
\text { HUMAN }\end{array}$ & $\begin{array}{l}\text { Alcohol dehydrogenase IB (Class I), beta polypeptide, } \\
\text { isoform CRA_a } \\
\text { OS=Homo sapiens GN=ADH1B PE }=4 \mathrm{SV}=1\end{array}$ & 0.299 \\
\hline 2 & $\begin{array}{l}\text { sp|P07327|ADH1A } \\
\text { HUMAN }\end{array}$ & $\begin{array}{l}\text { Alcohol dehydrogenase } 1 \mathrm{~A} \mathrm{OS}=\text { Homo sapiens } \mathrm{GN}=\mathrm{ADH} 1 \mathrm{~A} \\
\qquad \mathrm{PE}=1 \mathrm{SV}=2\end{array}$ & 0.399 \\
\hline 3 & $\begin{array}{l}\text { sp|P08319|ADH4 } \\
\text { HUMAN }\end{array}$ & $\begin{array}{l}\text { Alcohol dehydrogenase } 4 \mathrm{OS}=\text { Homo sapiens } \mathrm{GN}=\mathrm{ADH} 4 \\
\qquad \mathrm{PE}=1 \mathrm{SV}=5\end{array}$ & 0.438 \\
\hline 4 & $\begin{array}{l}\text { sp }|\mathrm{Q} 06278| \mathrm{AOXA}_{-} \\
\text {HUMAN }\end{array}$ & $\begin{array}{l}\text { Aldehyde oxidase } \mathrm{OS}=\text { Homo sapiens } \mathrm{GN}=\mathrm{AOX} 1 \mathrm{PE}=1 \\
\qquad \mathrm{SV}=2\end{array}$ & 0.68 \\
\hline 5 & $\begin{array}{l}\text { sp } \mid \text { P28332|ADH6 } \\
\text { HUMAN }\end{array}$ & $\begin{array}{l}\text { Alcohol dehydrogenase } 6 \mathrm{OS}=\text { Homo sapiens } \mathrm{GN}=\mathrm{ADH} 6 \\
\qquad \mathrm{PE}=1 \mathrm{SV}=2\end{array}$ & 0.721 \\
\hline 6 & $\begin{array}{l}\operatorname{tr} \mid \text { V9HVX6|V9HVX6 } \\
\text { HUMAN }\end{array}$ & $\begin{array}{l}\text { Epididymis luminal protein } 9 \mathrm{OS}=\text { Homo sapiens } \\
\qquad \mathrm{GN}=\mathrm{HEL}-9 \mathrm{PE}=2 \mathrm{SV}=1\end{array}$ & 0.808 \\
\hline
\end{tabular}

Table 3: Main clinical and biochemical characteristics of patients with liver transplant and the control group

\begin{tabular}{|c|c|c|c|c|c|}
\hline & class A & class B & class $\mathrm{C}$ & class D & class $\mathbf{E}$ \\
\hline Peripheral samples (n) & 9 & 9 & 9 & 9 & 9 \\
\hline Ages (years) & $44 \pm 12$ & $47 \pm 15$ & $47 \pm 15$ & $47 \pm 15$ & $47 \pm 15$ \\
\hline Sex(male/female) & $8 / 1$ & $8 / 1$ & $8 / 1$ & $8 / 1$ & $8 / 1$ \\
\hline ALT (IU/L) & $25.3 \pm 9.0$ & $80.2 \pm 20.1$ & $315.7 \pm 60.3$ & $178.5 \pm 39.8$ & $81.1 \pm 29.4$ \\
\hline AST(IU/L) & $21.7 \pm 7.9$ & $65.5 \pm 22.3$ & $293.8 \pm 62.5$ & $161.4 \pm 41.5$ & $69.5 \pm 31.8$ \\
\hline
\end{tabular}

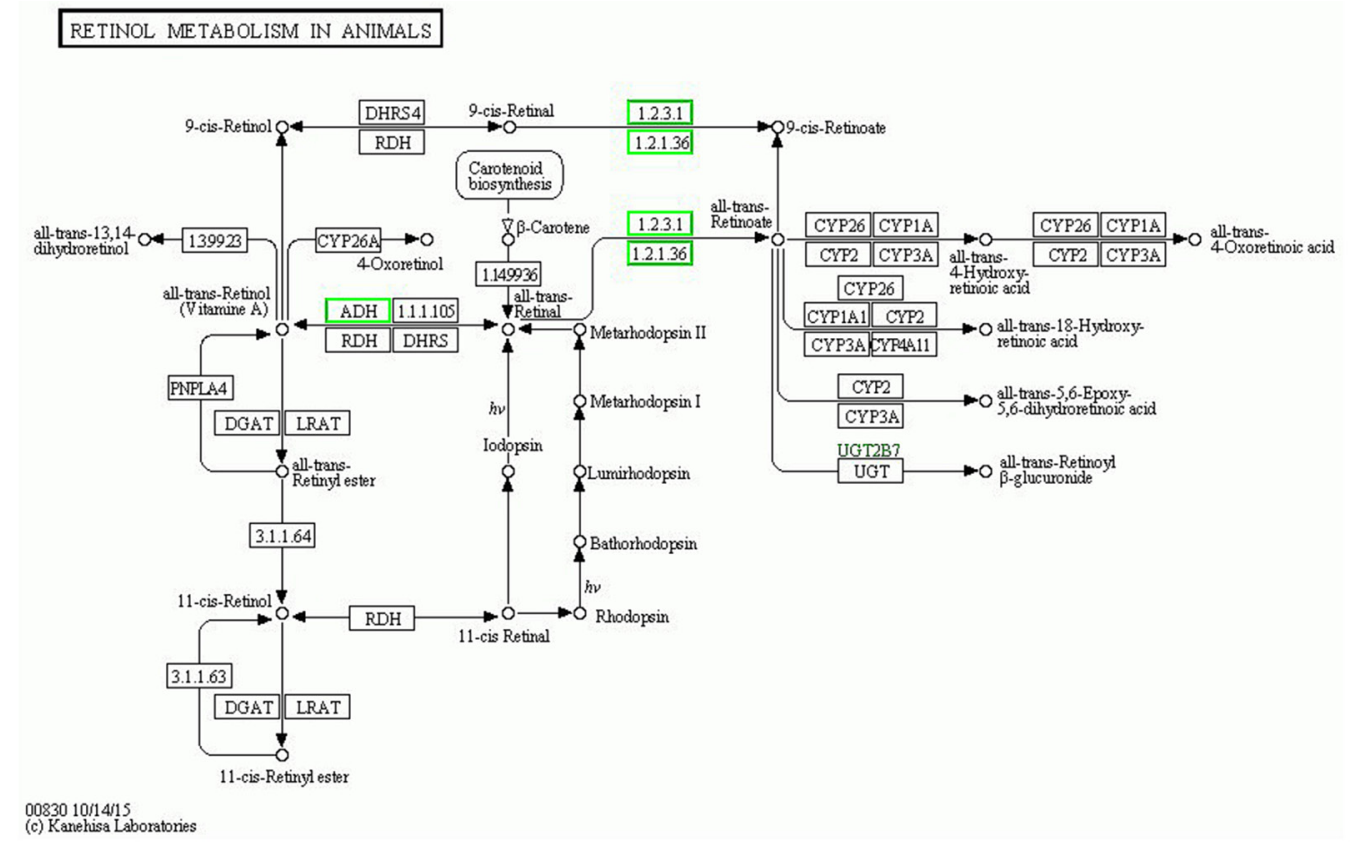

Figure 3: The KEGG pathway of "retinol metabolism". Down-regulated proteins are marked with with green borders and non-change proteins are marked with black borders. 
diagnosis. However, further investigation of the functions of these proteins, as well as of the proteins with high fold changes in liver cancer identified herein, is needed.

\section{MATERIALS AND METHODS}

Samples. Serum samples were obtained from liver transplant patients between October 2014 and August 2015 at the Guilin $181^{\text {st }}$ Hospital (Guilin No. 181 Hospital officially changed its name to Guilin No. 924 Hospital), Guangxi, China. All patients were transplanted for HCC.

Serum samples were collected from 9 healthy volunteers who served as controls (class A) and from 9 liver transplant patients at different timepoints as follows: before transplantation (class B) and after transplantation on the 1st (class C), the 3rd (class D) and the 7th (class E) days. The main clinical and biochemical characteristics of liver transplant patients and the control group are shown in Table 3.

This study was performed according to the guidelines set forth by the Guilin 181st Hospital and abides by the Declaration of Helsinki on ethical principles for medical research involving human subjects. Written informed consent was obtained from all the subjects or their guardians.

\section{Sample preparation}

Serum $(5 \mathrm{ml})$ was collected from the enrolled subjects in a coagulation tube; the serum was separated, and $100 \mu \mathrm{l}$ aliquots were stored at $-80^{\circ} \mathrm{C}$ until further use.

\section{ITRAQ}

The concentration of the extracted protein was measured using the Bradford method. According to the concentration results, $30 \mu \mathrm{g}$ of protein was removed from each sample for electrophoresis. Then, $100 \mu \mathrm{g}$ of protein was accurately removed for digestion from each sample solution.

After trypsin digestion, the peptides were vacuum centrifuged to dryness. The iTRAQ labelling of peptide samples was performed using the iTRAQ Reagent 8-plex Kit according to the manufacturer's protocol. The peptides labelled with respective isobaric tags were incubated for $2 \mathrm{~h}$. The iTRAQ-labelled peptides were fractionated using RP.

\section{Peptide fractionation by RP chromatography}

For RP chromatography using the Shimadzu LC20AB HPLC Pump System, the peptides from digestion were reconstituted with buffer A (5\% acetonitrile, 95\% $\mathrm{H} 2 \mathrm{O}$, adjusted to $\mathrm{pH} 9.8$ with ammonia) to $2 \mathrm{ml}$ and loaded onto a $4.6 \times 250 \mathrm{~mm}$ Gemini C18 column containing
$5 \mu \mathrm{m}$ particles (Phenomenex). The peptides were eluted at a flow rate of $1 \mathrm{~mL} / \mathrm{min}$ with a gradient of $5 \%$ buffer B (5\% H2O, 95\% acetonitrile, adjusted to $\mathrm{pH} 9.8$ with ammonia) for $10 \mathrm{~min}, 5-35 \%$ buffer B for $40 \mathrm{~min}$, and 35 $95 \%$ buffer B for $1 \mathrm{~min}$. The system was then maintained in $95 \%$ buffer B for 3 min and decreased to $5 \%$ within $1 \mathrm{~min}$ before equilibrating with $5 \%$ buffer B for $10 \mathrm{~min}$. Elution was monitored by measuring absorbance at 214 $\mathrm{nm}$, and fractions were collected every $1 \mathrm{~min}$. The eluted peptides were pooled as 20 fractions and vacuum-dried.

\section{LC-ESI-MS/MS analysis based on Triple TOF 5600}

Each fraction was resuspended in buffer A (5\% acetonitrile, $0.1 \%$ FA) and centrifuged at $20,000 \times \mathrm{g}$ for $10 \mathrm{~min}$, and the final concentration of peptide was approximately $0.5 \mathrm{mg} / \mathrm{mL}$. The supernatant was loaded on a LC-20AD Nano HPLC (Shimadzu, Kyoto, Japan) by the autosampler onto a $2 \mathrm{~cm} \mathrm{C18} \mathrm{trap} \mathrm{column.} \mathrm{Then,} \mathrm{the}$ peptides were eluted into a $18 \mathrm{~cm}$ analytical $\mathrm{C} 18$ column (inner diameter $75 \mathrm{~mm}$, packed in-house). The samples were loaded at $8 \mathrm{~mL} / \mathrm{min}$ for $4 \mathrm{~min}$, continued by a $41 \mathrm{~min}$ gradient running at $300 \mathrm{~nL} / \mathrm{min}$ from 5 to $35 \%$ buffer B ( $95 \%$ acetonitrile, $0.1 \% \mathrm{FA}$ ), followed by a 5 min linear gradient to $80 \%$ buffer B; the samples were maintained at $80 \%$ for $5 \mathrm{~min}$ and finally returned to $5 \%$ for $1 \mathrm{~min}$.

\section{Bioinformatic pipeline}

After the quantification of proteins, all the proteins with a false discovery rate (FDR) of less than $1 \%$ proceeded with the downstream analysis, including GO, COG and Pathway. Further, we performed deep analysis based on differentially expressed proteins, including Gene Ontology (GO) enrichment analysis, KEGG pathway enrichment analysis and cluster analysis.

\section{ACKNOWLEDGMENTS AND FUNDING}

The authors thank the patients and healthy volunteers who participated in the study and the members of staff for their assistance. This study was supported by the National Natural Science Foundation of China (Grant No. 81671596), the Science and Technology Planning Project of Guangdong Province, China (No. 2016A050503009), the Science and Technology Plan of Shenzhen (No. JCYJ20160422164313440), the Science and Technology Plan of Shenzhen (No. JCYJ20170307095606266), the Guangxi Natural Science Foundation (No. 2017GXNSFAA198185), the Guilin Research and Technology Development Project contract, the Scientific and Technological Innovation Ability and Condition Construction (No. 20170117-1), the National Natural Science Foundation of China (81670596) and the Guangxi Science and Technology Development Project (14124003-8). 


\section{CONFLICTS OF INTEREST}

The authors have no conflicts of interest.

\section{REFERENCES}

1. Affo S, Yu L, Schwabe RF. The role of cancer-associated fibroblasts and fibrosis in liver cancer. Annu Rev Pathol. 2017; 12:153-186.

2. Pinheiro RS, Waisberg DR, Nacif LS, Rocha-Santos V, Arantes RM, Ducatti L, Martino RB, Lai Q, Andraus W, D'Albuquerque LAC. Living donor liver transplantation for hepatocellular cancer: An (almost) exclusive Eastern procedure? Transl Gastroenterol Hepatol. 2017; 2:68.

3. Sui W, Zhang R, Chen J, He H, Cui Z, Ou M, Li W, Qi S, Wen J, Lin X, Dai Y. Quantitative proteomic analysis of Down syndrome in the umbilical cord blood using iTRAQ. Mol Med Rep. 2015; 11:1391-1399.

4. Sun C, Song C, Ma Z, Xu K, Zhang Y, Jin H, Tong S, Ding W, Xia G, Ding Q. Periostin identified as a potential biomarker of prostate cancer by iTRAQ-proteomics analysis of prostate biopsy. Proteome Sci. 2011; 9:22.

5. Brosch M, Yu L, Hubbard T, Choudhary J. Accurate and sensitive peptide identification with mascot percolator. Journal of Proteome Research. 2009; 8:3176-3181.

6. Blomhoff R, Wake K. Perisinusoidal stellate cells of the liver: important roles in retinol metabolism and fibrosis. FASEB J. 1991; 5:271-7.
7. Schäfer BW, Wicki R, Engelkamp D, Mattei MG, Heizmann $\mathrm{CW}$. Isolation of a YAC clone covering a cluster of nine S100 genes on human chromosome 1q21: rationale for a new nomenclature of the $\mathrm{S} 100$ calcium-binding protein family. Genomics. 1995; 25:638-43.

8. https://www.ncbi.nlm.nih.gov/gene? $\mathrm{Db}=$ gene $\& \mathrm{Cmd}=$ Show DetailView\&TermToSearch $=6286$.

9. Chandramouli A, Mercado-Pimentel ME, Hutchinson A, Gibadulinová A, Olson ER, Dickinson S, Shañas R, Davenport J, Owens J, Bhattacharyya AK, Regan JW, Pastorekova S, Arumugam T, et al. The induction of S100p expression by the Prostaglandin $\mathrm{E}_{2}\left(\mathrm{PGE}_{2}\right) / \mathrm{EP} 4$ receptor signaling pathway in colon cancer cells. Cancer Biol Ther. 2010; 10:1056-66.

10. Dong L, Wang F, Yin X, Chen L, Li G, Lin F, Ni W, Wu J, Jin R, Jiang L. Overexpression of S100P promotes colorectal cancer metastasis and decreases chemosensitivity to 5-FU in vitro. Mol Cell Biochem. 2014; 389:257-264.

11. Dong H, Ge X, Shen Y, Chen L, Kong Y, Zhang H, Man X, Tang L, Yuan H, Wang H, Zhao G, Jin W. Gene expression profile analysis of human hepatocellular carcinoma using SAGE and LongSAGE. BMC Med Genomics. 2009; 2:5.

12. https://en.wikipedia.org/wiki/Aldehyde_oxidase. 